\title{
EIF2AK1 wt Allele
}

National Cancer Institute

\section{Source}

National Cancer Institute. EIF2AK1 wt Allele. NCI Thesaurus. Code C97324.

Human EIF2AK1 wild-type allele is located within 7p22 and is approximately $35 \mathrm{~kb}$ in length. This allele, which encodes eukaryotic translation initiation factor 2-alpha kinase 1 protein, is involved in the inhibition of translation initiation in response to various stress stimuli. 